\title{
OPTIMASI MULTI RESPON PADA PROSES PEMBUATAN PADUAN ALUMINIUM/FL Y ASH MENGGUNAKAN METALLURGI SERBUK
}

\author{
Djoko W. Karmiadji), Dicky Seprianto ${ }^{2)}$ \\ 1) B2TKS-BPPT, Kawasan PUSPIPTEK Setu-Serpong, Tangerang Selatan \\ ${ }^{2)}$ Staf Pengajar Jurusan Teknik Mesin Politeknik Negeri Sriwijaya
}

\begin{abstract}
Abstrak
Abu batubara (fly ash) merupakan limbah dari hasil pembakaran batubara pada PLTU yang dapat dimanfaatkan dalam paduan aluminium. Pada penelitian ini dibuat paduan aluminium dengan fly ash yang menggunakan metode metallurgi serbuk. Serbuk aluminium berbentuk tidak beraturan dan ukuran partikel yang homogen sedangkan serbuk fly ash diperoleh dari PLTU Bukit Asam dengan ukuran partikel $=50 \mu \mathrm{m}$. Serbuk aluminium dicampur dengan berat fraksi fly ash sebesar 5\% selama 1 jam kemudian dipadatkan dengan tekanan pemadatan (kompaksi) $139 \mathrm{~N} / \mathrm{mm}^{2}$ dan $275 \mathrm{~N} / \mathrm{mm}^{2}$ menggunakan metode cold isostatic pressing.

Green body yang dihasilkan disinter dengan suhu $550^{\circ} \mathrm{C}$ dan waktu penahanan suhu (holding time) 60 dan 180 menit. Metode eksperimen desain faktorial 2 level dengan bantuan perangkat lunak design-expert ${ }^{\circledR}$ digunakan untuk menentukan faktor-faktor yang berpengaruh serta kondisi optimum dari kekerasan brinell, kuat tekan dan densitas paduan aluminium-5\% fly ash. Hasil dari analisa data eksperimen menggunakan ANOVA didapat bahwa faktor kompaksi dan holding time mempunyai pengaruh signifikan terhadap kekerasan, kuat tekan serta densitas paduan aluminium-5\% fly ash.
\end{abstract}

Kata kunci : Aluminium, fly ash, kompaksi, holding time, desain eksperimen, optimasi

\begin{abstract}
Fly ash, the waste resuled from the coal burning in power plant, can be mixed in aluminium alloys. This research is performed by mixing the aluminium alloy with the fly ash using the methods of powder metallurgi. The shape of aluminium powder is irregular and the homogeneous particle size fly ash powder is obtained from the Bukit Asam power plant with the particle size $=50 \mu \mathrm{m}$. The aluminium powder is mixed with $5 \%$ weight fraction of fly ash for 1 hour and then the powder is compacted with the pressure of $139 \mathrm{~N} / \mathrm{mm}^{2}$ and $275 \mathrm{~N} / \mathrm{mm}^{2}$ by using the cold isostatic pressing method.

The green body of compaction result is sintered untill the temperature of $550^{\circ} \mathrm{C}$ with two holding times such as 60 and 180 minutes. Two level factorial design experimental method with the help of Design-Expert@ software is used to determine the factors that influence as well as the optimum condition of the brinell hardness, compressive strength and density of aluminum alloy-5\% fly ash. The analysis results of experimental data by using ANOVA are shown that compaction factor and holding time have a significant influence on hardness, compressive strength and density of aluminum alloy- $5 \%$ fly ash.
\end{abstract}

Key words : Aluminium, fly ash, compacting, holding time, experimental design, optimization

\section{PENDAHULUAN}

Abu batubara (fly ash) merupakan limbah padat yang dihasilkan oleh pembakaran batubara pada proses pembentukanlogam secara plastis dengan memberikan gaya tekan pada logam yang akan dibentuk (penempaan) dan pembangkit listrik tenaga uap berbahan bakar batu bara jumlahnya dilndonesia sangat banyak, pada tahun 2006 mencapai 3,3 juta ton dan akan terus meningkat, limbah ini perlu mendapat 
perhatian yang serius karena berpotensi besar menjadi masalah lingkungan, bahkan Kementerian Lingkungan Hidup (KLH) telah menetapkannya sebagai Bahan Berbahaya dan Beracun (B3) karena kandungan logamlogam berat yang bersifat toksik. Namun di sisi lain, telah diketahui pula bahwa abu batubara mengandung unsur-unsur sebagai bahan agregat dan beberapa logam yang mempunyai nilai tinggi, sehingga abu terbang mempunyai potensi untuk dimanfaatkan ${ }^{1)}$.

Berbagai penelitian telah banyak dilakukan dengan harapan, bukan saja dapat mengatasi masalah lingkungan di PLTU berbahan bakar batu bara, tetapi sekaligus dapat memberi nilai tambah terhadap limbah. Hal itu merupakan bagian penting dari konsep sustainable production (memanfaatkan dan memberi nilai tambah pada limbah industri). Konsep sustainable production adalah konsep industri masa depan yang sangat penting, terutama bagi dunia industri ${ }^{2)}$.

Aluminium merupakan salah satu logam non ferrous yang memiliki banyak keistimewaan antara lain tahan korosi, konduktivitas thermal yang baik, ringan serta sifat dekoratif, sehingga banyak digunakan dalam industri otomotif. Pada saat ini abu batubara mempunyai nilai ekonomis yang rendah sehingga pemanfaatan material yang dibuat dengan paduan aluminium fly-ash (ALFA) sangat menguntungkan dilihat dari segi ekonomi dibandingkan dengan paduan yang lain. Serbuk aluminium sebagai matrik dan abu batubara sebagai penguat merupakan paduan logam yang dapat dibuat dengan metode serbuk. Keuntungannya adalah pembuatan komponen relatif lebih murah, produk yang dihasilkan langsung dapat digunakan dengan sedikit proses permesinan serta dapat diproduksi dalam skala kecil maupun besar ${ }^{7}$.

Proses metallurgi serbuk umumnya menghasilkan porositas pada produknya, yang berpengaruh terhadap sifat fisis dan mekanisnya. Proses lain dalam pembuatan paduan adalah dengan pengecoran akan tetapi pada proses pengecoran mempunyai kendala yaitu sulit membuat paduan yang homogen, karena partikel penguat biasanya mengendap atau mengapung yang disebabkan perbedaan berat jenis.

Pembuatan paduan aluminium-fly ash (ALFA) menggunakan teknik gravity dan squeeze casting terdapat kekurang seragaman distribusi fly ash ${ }^{3)}$. Oleh karena itu pada penelitian ini penulis mencoba meneliti paduan yang dibuat dari serbuk aluminium sebagai matrik dan fly ash sebagai penguat dengan cara pressureless sintering (kompaksi dan sintering dilakukan tidak secara bersamaan). Fly ash mempunyai titik lebur sekitar $1300^{\circ} \mathrm{C}^{4)}$ dan berdasarkan uji komposisi kimia fly ash mengandung CAS $\left(\mathrm{C}_{\mathrm{a}} \mathrm{O}-\mathrm{Al}_{2} \mathrm{03}-\mathrm{S}_{\mathrm{i}} \mathrm{O}_{2}\right)$ dalam jumlah besar ${ }^{5}$. Proses pembuatan paduan aluminium/fly ash dengan menggunakan metode serbuk pada secara umum dapat dibagi menjadi 4 , yaitu ${ }^{6 / 8)}$ :

1. Persiapan serbuk fly ash

(Shieving dan kalsinasi)

2. Proses pencampuran

(blending / mixing)

3. Proses kompaksi

4. Proses Sintering

Penelitian ini dilakukan untuk mengetahui pengaruh serta persen kontribusi dari kompaksi dan holding time pada proses pembuatan paduan aluminium/fly ash dengan fraksi penguat fly ash $5 \%$ pada suhu sinter $550{ }^{\circ} \mathrm{C}$ terhadap kekerasan (brinell hardness), kuat tekan (compression strength) dan densitas optimum dari paduan, serta validasi data hasil pengujian yang dilakukan dengan analysis of variance dengan bantuan perangkat lunak design-expert@.

\section{BAHAN DAN METODA}

Pengertian metode penelitian secara umum adalah membahas bagaimana secara berurut suatu eksperimen dilakukan, yaitu dengan alat apa dan prosedur bagaimana suatu penelitian dilakukan. Ada dua aspek ekeperimen, yaitu desain eksperimen dan analisa statistik data. Desain eksperimen adalah proses perancangan eksperimen untuk mengumpulkan data yang tepat sehingga dapat dianalisa dengan menggunakan metode statistik dan mendapatkan kesimpulan yang bersifat objektif dan valid $^{9}$.

Parameter yang berpengaruh terhadap karakteristik paduan aluminium/fly ash sangat banyak, oleh karena itu diperlukan metode desain eksperimen untuk mendapatkan hasil yang baik. Pada penelitian ini parameter yang dipilih adalah tekanan pemadatan (kompaksi) dan waktu penahanan suhu sinter (holding time) terhadap kekerasan, kuat tekan serta densitas spesimen paduan dengan fraksi penguat fly ash $5 \%$ pada suhu sinter $550{ }^{\circ} \mathrm{C}$, metode eksperimen yang digunakan adalah full factorial design dengan 2 level dan 2 faktor, kemudian dilanjutkan analysis of variance (ANOVA) dengan bantuan perangkat lunak design-expert versi $8^{12)}$.

\subsection{Desain Eksperimen Faktorial}

Dari keseluruhan parameter proses yang dapat dikendalikan, disusun suatu faktor-faktor eksperimen yang berpengaruh 
terhadap densitas, kekerasan dan kuat tekan dari spesimen hasil paduan alumnium/fly ash yang dibuat dengan metode metallurgi serbuk serta dilakukan pada temperatur sintering $550^{\circ} \mathrm{C}$ dan fraksi penguat fly ash sebesar $5 \%$ dari paduan. Penelitian ini direncanakan menggunakan metode eksperimen 2 level factorial design, sehingga dibutuhkan 4 spesimen pengujian untuk faktor yang telah ditentukan sebagai berikut:

a).Tekanan pemadatan (kompaksi) pada proses pembuatan green body.

- Jumlah leve/dua

- Nilai minimum $139 \mathrm{~N} / \mathrm{mm}^{2}$

- Nilai maksimum $275 \mathrm{~N} / \mathrm{mm}^{2}$

b). Waktu penahanan suhu sintering (holding time).

- Jumlah leve/dua

- Nilai minimum 60 Menit

- Nilai maksimum 180 Menit

Faktor-faktor eksperimen yang akan dilakukan, ditunjukkan pada tabel 1.

Tabel 1. Faktor-Faktor Eksperimen

\begin{tabular}{|c|c|c|c|c|}
\hline \multirow{2}{*}{ No } & \multirow{2}{*}{$\begin{array}{l}\text { Faktor-Faktor } \\
\text { Terkontrol }\end{array}$} & \multirow{2}{*}{ Satuan } & \multicolumn{2}{|c|}{ Level } \\
\hline & & & Min & $\operatorname{Max}$ \\
\hline 1 & Kompaksi & $\mathrm{N} / \mathrm{mm}^{2}$ & 139 & 275 \\
\hline 2 & Holding time & Menit & 60 & 180 \\
\hline
\end{tabular}

Selanjutnya ditentukan kombinasi dari masing-masing faktor dan level untuk pembuatan spesimen uji yaitu :

1. Spesimen dengan kompaksi 139 $\mathrm{N} / \mathrm{mm}^{2}$ dan holding time 60 menit

2. Spesimen dengan kompaksi 139 $\mathrm{N} / \mathrm{mm}^{2}$ dan holding time 180 menit

3. Spesimen dengan kompaksi 275 $\mathrm{N} / \mathrm{mm} 2$ dan holding time 60 menit

4. Spesimen dengan kompaksi 275 $\mathrm{N} / \mathrm{mm}^{2}$ dan holding time 180 menit

Untuk setiap pengujian terhadap respon (kekerasan, kuat tekan dan densitas) diperlukan 4 spesimen uji dan dilakukan 3 kali pengulangan dengan parameter yang sama sehingga dibutuhkan sebanyak 12 spesimen uji untuk masing-masing respon yang akan diteliti.

\subsection{Prosedur Penelitian}

Fly-ash sebagai penguat terlebih dahulu dikalsinasi pada temperatur $900^{\circ} \mathrm{C}$ selama 3 jam, kemudian dilakukan uji komposisi. Tujuan dari kalsinasi adalah menghilangkan senyawa yang mudah menguap, selanjutnya diayak (shieving) untuk mendapatkan ukuran $\leq 50 \mu \mathrm{m}$. Setelah itu ditimbang sesuai porsi masing-masing yaitu dengan fraksi berat fly-ash 5\% dari paduan serbuk, sebagai bahan penguat. Kemudian dilakukan proses pencampuran serbuk menggunakan mesin pencampur (blending/mixing), hasil dari mixing dikeluarkan dan dimasukkan ke dalam cetakan (die). Selanjutnya dilakukan proses penekanan menggunakan mesin press hidrolik (Compacting) dengan variasi penekanan $139 \mathrm{~N} / \mathrm{mm}^{2}$ dan $275 \mathrm{~N} / \mathrm{mm}^{2}$ sehingga dihasilkan green body.

Spesimen-spesimen (green body) yang dihasilkan kemudian di sinter pada dapur pemanas dengan suhu $550^{\circ} \mathrm{C}$ dan dilakukan penahanan suhu (holding time) dengan variasi selama 60 menit dan 180 menit kemudian didinginkan pada suhu ruang. Setelah proses sinter selesai selanjutnya dilakukan pengujian untuk mendapatkan data yang akan diolah dengan bantuan perangkat lunak design expert sehingga dapat diketahui pengaruh kompaksi dan holding time pada proses pembuatan spesimen dari paduan aluminium/fly ash.

Adapun pengujian yang akan dilakukan pada spesimen yang telah dibuat adalah:

1. Pengujian kekerasan (brinell hardness)

2. Pengujian kuat tekan (compression strength)

3. Pengujian densitas

4. Uji komposisi

5. Pengamatan struktur mikro

Hasil pengujian di analisa untuk mengetahui karakteristik optimum dari paduan aluminium/fly ash. Secara skematis prosedur dari penelitian yang akan dilakukan ditunjukkan pada gambar 1. Pengujian kekerasan, kuat tekan, densitas dan pengamatan struktur mikro terhadap paduan aluminium/fly ash dilakukan di laboratorium Jurusan Teknik Mesin Politeknik Negeri Sriwijaya, sedangkan uji komposisi fly ash dan paduan aluminium dengan $5 \%$ fly ash dilakukan di Center For Material Processing And Failure Analysis (CFMPA) Departemen Teknik Metalurgi dan Material Universitas Indonesia. Fly ash terlebih dahulu dikalsinasi pada temperatur $900{ }^{\circ} \mathrm{C}$, selama 3 jam dengan tujuan untuk menghilangkan senyawa yang mudah menguap, sehingga lost of ignition (loi) pada saat sintering dapat dihindari ${ }^{11)}$.

Setelah proses kalsinasi selesai selanjutnya fly ash diayak dengan menggunakan Shieving Machine Merk RETSCH dengan ukuran tingkatan terendah sebesar $0.050 \mathrm{~mm}$ sehingga diperoleh serbuk fly ash dengan ukuran $\leq 50 \mu \mathrm{m}$. Abu batubara sebelum dikalsinasi berwarna abu-abu, sedangkan setelah dikalsinasi 


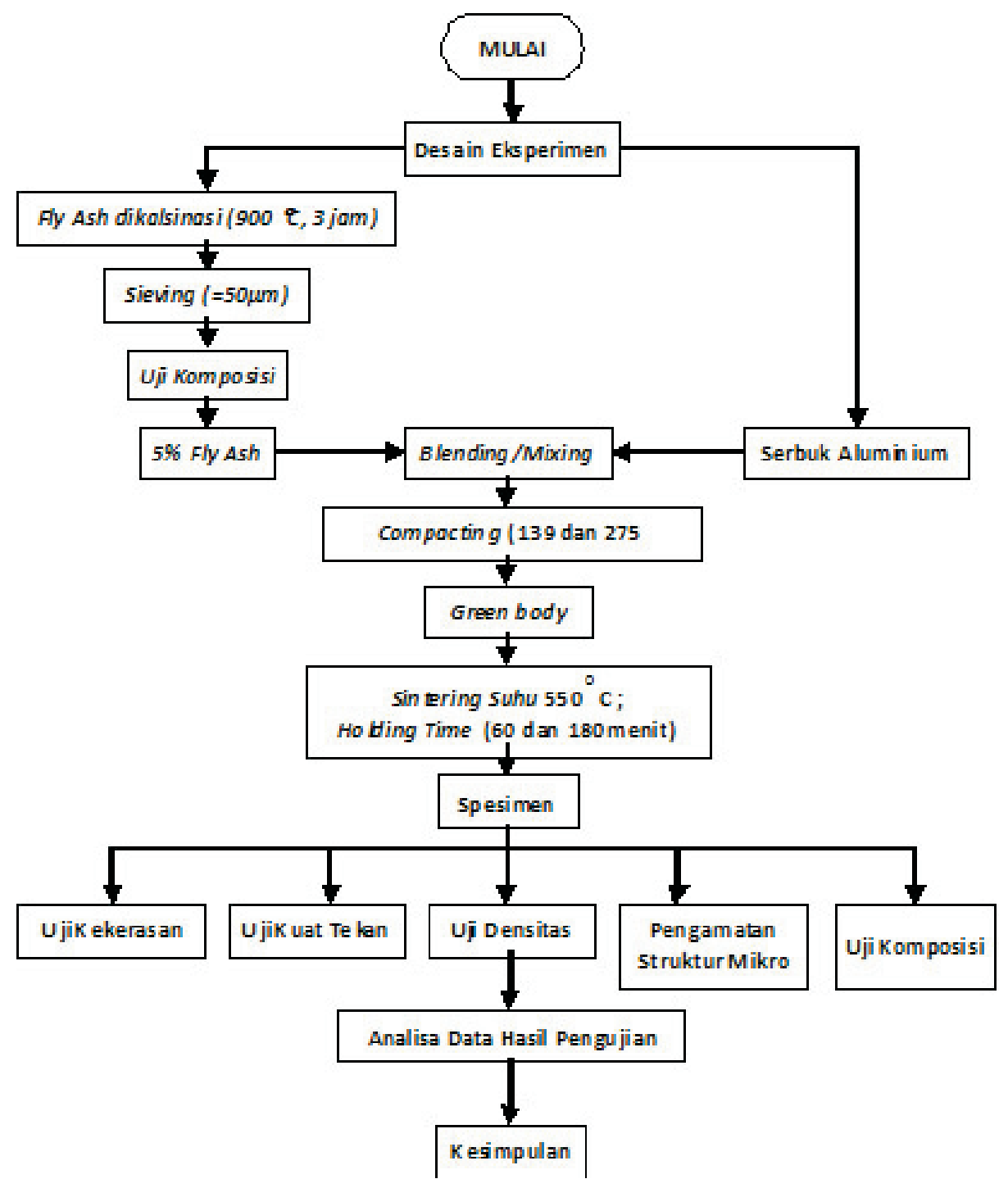

Gambar 1. Diagram Alir Penelitian

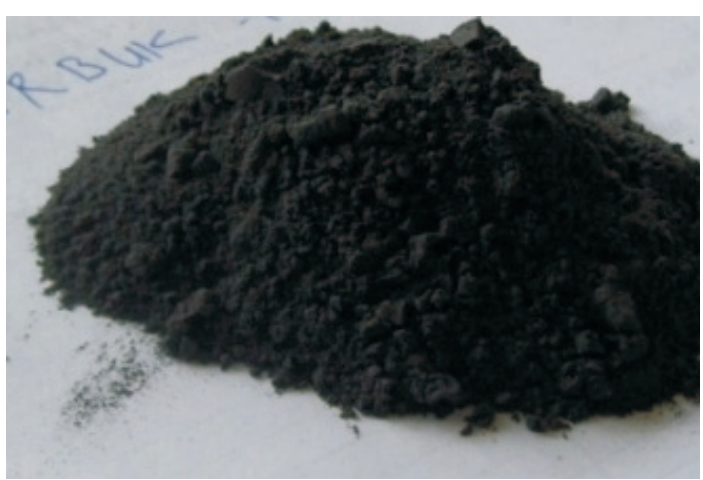

a) sebelum kalsinasi

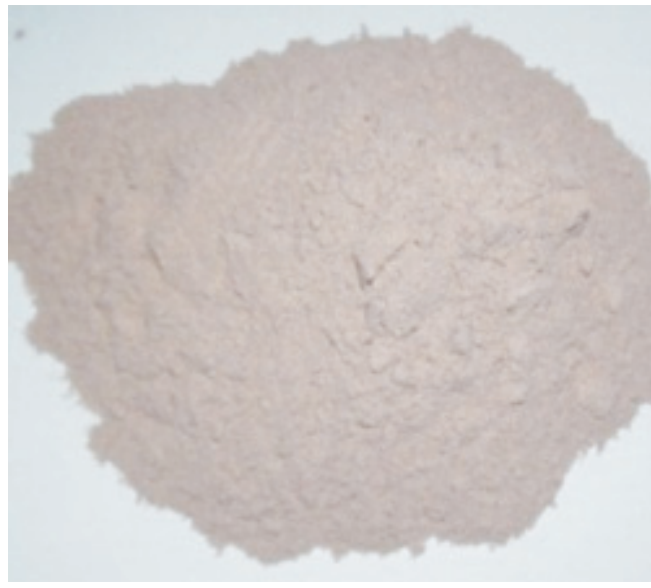

b) sesudah kalsinasi

Gambar 2. Fly Ash Sebelum Dikalsinasi 
berwarna merah muda ditunjukkan pada gambar 2. Proses selanjutnya adalah menentukan berat masing-masing serbuk dengan cara ditimbang menggunakan timbangan digital acis precision balance $A D$ 300. Fraksi berat fly ash sebagai penguat sebesar $5 \%$ dari paduan serbuk dengan komposisi berat serbuk aluminium sebesar $209 \mathrm{gr}$ dan serbuk fly ash sebesar $11 \mathrm{gr}$, sehingga didapat paduan serbuk dengan total berat $220 \mathrm{gr}$.

Setelah proses penimbangan serbuk selesai kemudian dilakukan pencampuran serbuk dengan tujuan untuk menggabungkan material serbuk yang mempunyai sifat kimia yang berbeda. Paduan serbuk aluminium dan fly ash yang telah ditimbang, dimasukkan ke dalam tabung keramik dan dilakukan proses blending/mixing menggunakan Ball Mill Merk Groschopp Viersen FRG pada gambar 3 selama 2 jam, dalam keadaan kering sehingga didapat campuran yang merata dan homogen.

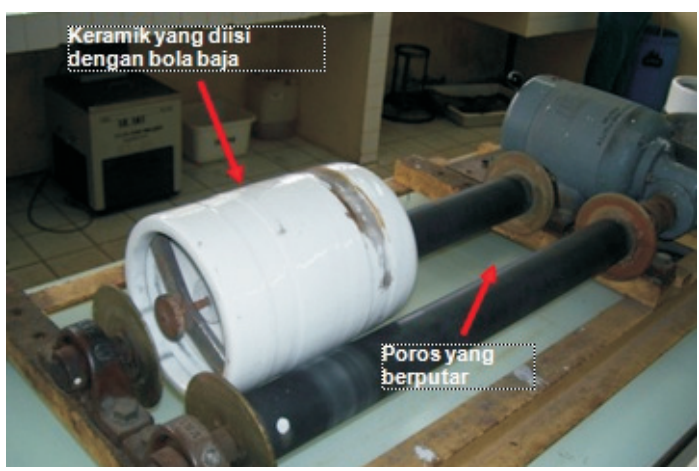

Gambar 3. Proses Blending/Mixing

Serbuk campuran dimasukkan ke dalam cetakan berbentuk silinder, sebelum serbuk mengalami penekanan dalam cetakan terlebih dahulu ditata supaya mempermudah proses penekanan. Metode penekanan yang digunakan dalam penelitian ini adalah cold compaction, menggunakan fortal hydraulic press machine dengan variasi gaya penekanan sebesar $139 \mathrm{~N} / \mathrm{mm}^{2}$ dan 275 $\mathrm{N} / \mathrm{mm}^{2}$, proses penekanan ditunjukkan pada gambar 4.

Proses sinter terhadap green body dilakukan dalam Muffle Furnace (merk Nabertherm) dengan suhu sinter $550{ }^{\circ} \mathrm{C}$ dengan kenaikan suhu rata-rata $1{ }^{\circ} \mathrm{C} /$ detik yang dimulai dari suhu ruang. Lama waktu penahan suhu sinter (holding time) divariasikan 60 dan 180 menit. Pemanasan dilakukan pada suhu 0,7 sampai $0,8 \mathrm{Tm}$ (melting temperature) dalam skala absolute yang disebut dengan solid state sintering atau solid phase sintering karena logam masih dalam keadaan padat selama proses.
Spesimen hasil sinter ditunjukkan pada gambar 5 .

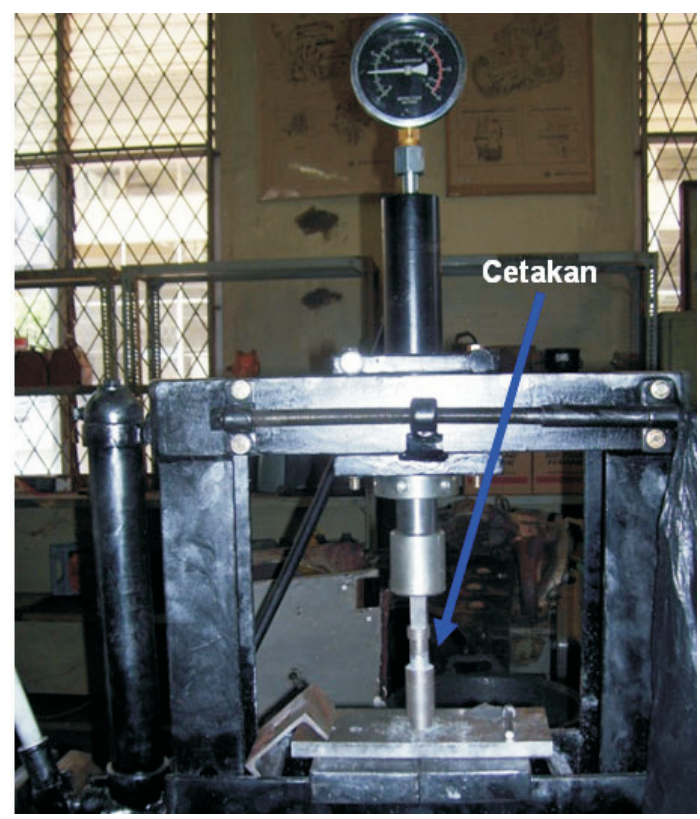

Gambar 4 : Proses Penekanan Paduan Serbuk

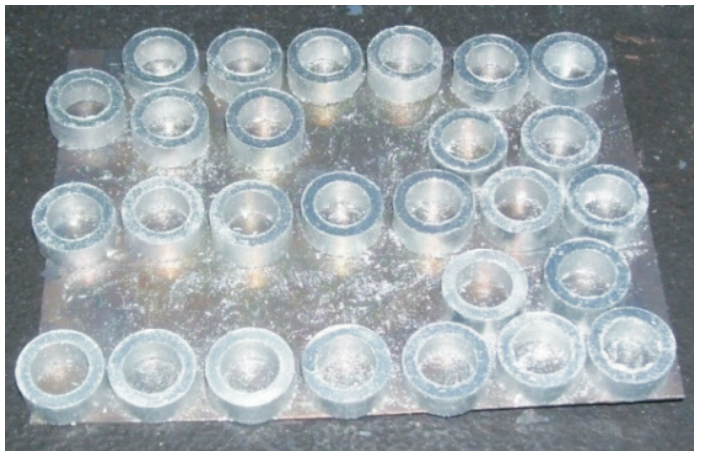

Gambar 5. Spesimen Hasil Proses Sinter

\section{HASIL DAN PEMBAHASAN}

Setelah dilakukan pengujianpengujian terhadap spesimen paduan serbuk aluminium dengan fly ash didapat data-data hasil pengujian yang akan dianalisa, sehingga dapat diketahui pengaruh tekanan pemadatan (kompaksi) dan waktu penahanan suhu sinter (holding time) pada spesimen uji dari paduan aluminium $/ 5 \%$ fly ash yang diproduksi dengan metode metallurgi serbuk terhadap kekerasan, kuat tekan dan densitas.

\subsection{Hasil Penelitian}

Data-data hasil pengujian selanjutnya diolah menggunakan ANOVA dengan bantuan perangkat lunak design-expert untuk 
Tabel 2. Hasil Pengujian Kekerasan, Kuat Tekan Dan Densitas Paduan Aluminium Dengan 5\% Fly Ash Yang Dilakukan 3 Kali Replikasi

\begin{tabular}{|c|c|c|c|c|c|c|}
\hline Std & Run & $\begin{array}{c}\text { A : Kompaksi } \\
\left(\mathbf{N} / \mathbf{m m}^{2}\right)\end{array}$ & $\begin{array}{c}\text { B: Holding time } \\
\text { (Menit) }\end{array}$ & $\begin{array}{c}\text { Kekerasan } \\
\left(\mathbf{N} / \mathbf{m m}^{2}\right)\end{array}$ & $\begin{array}{c}\text { Kuat Tekan } \\
\left(\mathbf{N} / \mathbf{m m}^{2}\right)\end{array}$ & $\begin{array}{c}\text { Densitas } \\
\left(\mathbf{g r}^{\mathbf{c}} \mathbf{c m}^{3}\right)\end{array}$ \\
\hline 4 & 1 & 275 & 60 & 88.890 & 179.49 & 3.000 \\
\hline 1 & 2 & 139 & 60 & 76.830 & 169.56 & 2.500 \\
\hline 10 & 3 & 275 & 180 & 101.674 & 198.41 & 3.714 \\
\hline 7 & 4 & 139 & 180 & 95.208 & 182.91 & 2.700 \\
\hline 8 & 5 & 139 & 180 & 95.199 & 183.21 & 2.700 \\
\hline 2 & 6 & 139 & 60 & 76.841 & 170.15 & 2.500 \\
\hline 11 & 7 & 275 & 180 & 101.657 & 198.38 & 3.571 \\
\hline 5 & 8 & 275 & 60 & 88.921 & 179.52 & 3.000 \\
\hline 9 & 9 & 139 & 180 & 95.189 & 183.14 & 2.778 \\
\hline 12 & 10 & 275 & 180 & 101.691 & 198.43 & 3.714 \\
\hline 6 & 11 & 275 & 60 & 88.858 & 179.45 & 3.000 \\
\hline 3 & 12 & 139 & 60 & 76.820 & 169.00 & 2.500 \\
\hline
\end{tabular}

mengetahui faktor-faktor yang berpengaruh terhadap respon (kekerasan, kuat tekan dan densitas) pada paduan aluminium $/ 5 \%$ fly ash yang dibuat dengan metode serbuk. Setelah ditentukan rancangan desain eksperimen, maka dilakukan pengujian secara acak terhadap 2 faktor dan 2 level dengan 3 kali replikasi. Hasil pengujian ditunjukkan pada tabel 2.

\subsection{Pembahasan}

ANOVA data hasil pengujian kekerasan spesimen, untuk mengetahui faktor-faktor yang berpengaruh, dilakukan perhitungan secara manual dengan tujuan melihat kesamaan hasil analisa dengan menggunakan perangkat lunak designexpert. Dari 12 kali observasi yang dilakukan maka didapat nilai minimum, maksimum, ratarata, standar deviasi dan rasio dari masingmasing respon dan faktor pada pengujian, kemudian dibuat dalam bentuk tabel 3 .

Analisa data hasil percobaan terhadap spesimen uji dengan metode 2 level factorial design dan ANOVA menggunakan perangkat lunak design expert diperoleh $\mathrm{F}_{\text {Hitung }}>\mathrm{F}_{\text {Tabel, }}$, sehingga dapat diambil kesimpulan bahwa faktor kompaksi dan holding time berpengaruh terhadap nilai kekerasan, kuat tekan dan densitas dari spesimen uji dengan tingkat keyakinan $95 \%(\alpha=0.05)$, serta datadata yang dianalisa memenuhi asumsi identik, independen dan berdistribusi normal dengan membandingkan residual dari masing-masing respon. Persentase kontribusi terbesar untuk masing-masing respon yaitu :

- Faktor holding time memberikan persentase kontribusi sebesar $72.14 \%$ terhadap kekerasan spesimen uji.

- Faktor holding time memberikan persentase kontribusi sebesar $61.20 \%$ terhadap kuat tekan spesimen uji.

- Faktor kompaksi memberikan persentase kontribusi sebesar $67.08 \%$ terhadap densitas spesimen uji.

Persamaan regresi linier yang dihasilkan dari analisa data hasil pengujian spesimen dengan bantuan perangkat lunak design expert ${ }^{\circledR}$ adalah:

Kekerasan $=$

$52.46723+0.10920 *$ kompaksi +0.20063 * holding time -0.000342157 * kompaksi * holding time.

Kuat tekan $=$

$155,41729+0,053125^{*}$ kompaksi $+0,066730$

* holding time $+3,30678 \mathrm{E}-04$ * kompaksi * holding time

Densitas $=$

2,10124 + 2,0561E-03 * kompaksi - 1,87114E03 * holding time $+2,70062 \mathrm{E}-05$ * kompaksi * holding time

Berdasarkan hasil pengujian komposisi abu batubara didapat unsur-unsur logam yang dapat dimanfaatkan dalam paduan aluminium dengan menggunakan metode metallurgi serbuk sehingga dapat meningkatkan kekerasan dan kuat tekan paduan aluminium. Sedangkan dari pengamatan struktur mikro dapat diketahui penyebaran fly ash sudah cukup baik 
sehingga parameter proses dapat digunakan, walaupun porositas yang terjadi tidak dapat dihindari dengan menggunakan metode metallurgi serbuk.

Tabel 3. Rata-Rata, Standar Deviasi, Dan Rasio Dari Hasil Pengujian Kekerasan, Kuat Tekan Dan Densitas Paduan Aluminium $/ 5 \%$ Fly Ash

\begin{tabular}{|l|c|c|c|c|c|c|}
\hline & \multicolumn{3}{c|}{ Design Model : 2FI } & \multicolumn{2}{c|}{ Design Type : 2 Level Factorial } & \multicolumn{3}{c|}{ Runs : 12 } \\
\hline & A & B & & \multicolumn{3}{c|}{ Response } \\
\hline Name & Kompaksi & Holding Time & Name & Kekerasan & Kuat tekan & Densitas \\
\hline Units & $\mathrm{N} / \mathrm{mm}^{2}$ & Menit & Units & $\mathrm{N} / \mathrm{mm}^{2}$ & $\mathrm{~N} / \mathrm{mm}^{2}$ & $\mathrm{gr} / \mathrm{cm}^{3}$ \\
\hline Minimum & 139 & 60 & Observasi & 12 & 12 & 12 \\
\hline Maximum & 275 & 180 & Analysis & factorial & factorial & factorial \\
\hline Mean & 207 & 120 & Minimum & 76,820 & 169.00 & 2,500 \\
\hline $\mathbf{- 1}$ (code) & 139 & 60 & Maximum & 101,691 & 198.43 & 3,714 \\
\hline $\mathbf{+ 1}$ (code) & 275 & 180 & Mean & 90,6482 & 182.636 & 2,97315 \\
\hline Std. Dev & 68 & 60 & Std. Dev & 9,57699 & 10,8288 & 0,459018 \\
& & & Ratio & 1,32376 & 1,17414 & 1,48571 \\
\hline
\end{tabular}

Tabel 4. Analysis Of Variance (ANOVA) Untuk Kekerasan Spesimen Uji

\begin{tabular}{|c|c|c|c|c|c|c|}
\hline Source & $\begin{array}{c}\text { Sum of } \\
\text { Squares }\end{array}$ & $\begin{array}{c}\text { Degrees of } \\
\text { Freedom }\end{array}$ & $\begin{array}{c}\text { Mean } \\
\text { Square }\end{array}$ & Fo & FTabel & $\begin{array}{c}\text { Persentase } \\
\text { kontribusi }\end{array}$ \\
\hline Model & 1008.903 & 3 & 336.30 & $9.077 \mathrm{E}+05$ & 4.07 & $99.99 \%$ \\
\hline A-Kompaksi & 257.650 & 1 & 257.65 & $6.954 \mathrm{E}+05$ & 5.32 & $25.54 \%$ \\
\hline B-Holding time & 727.866 & 1 & 727.87 & $1.965 \mathrm{E}+06$ & 5.32 & $72.14 \%$ \\
\hline AB & 23.386 & 1 & 23.39 & 63119.55 & 5.32 & $2.31 \%$ \\
\hline Error & $2.964 \mathrm{E}-03$ & 8 & $3.705 \mathrm{E}-04$ & & & \\
\hline Total & 1008.906 & 11 & & & & \\
\hline
\end{tabular}

Tabel 4. Analysis Of Variance (ANOVA) Untuk Kekerasan Spesimen Uji

\begin{tabular}{|c|c|c|c|c|c|c|}
\hline Response & 2 & \multicolumn{3}{|c|}{ KUAT TEKAN } & & \\
\hline \multicolumn{5}{|c|}{ ANOVA for selected factorial model } & & \\
\hline \multicolumn{7}{|c|}{ Analysis of variance table } \\
\hline Source & $\begin{array}{l}\text { Sum of } \\
\text { Squares }\end{array}$ & df & $\begin{array}{l}\text { Mean } \\
\text { Square }\end{array}$ & $\begin{array}{c}F \\
\text { Value } \\
\end{array}$ & $\begin{array}{c}F^{*} \\
(\alpha=0.05)\end{array}$ & \\
\hline Model & 1289.19 & 3 & 429.73 & 4971.81 & 4.07 & significant \\
\hline A-Kompaksi & 477.92 & 1 & 477.92 & 5529.43 & 5.32 & \\
\hline B-Holding time & 789.43 & 1 & 789.43 & 9133.37 & 5.32 & \\
\hline$A B$ & 21.84 & 1 & 21.84 & 252.72 & 5.32 & \\
\hline Pure Error & 0.69 & 8 & 0.086 & & & \\
\hline Cor Total & 1289.88 & 11 & & & & \\
\hline
\end{tabular}


Optimasi Multi Respon Pada Proses Pembuatan Paduan Aluminium/Fly Ash Menggunakan Metallurgi Serbuk (Djoko W. Karmiadji, Dicky Seprianto)

Tabel 6. Analysis Of Variance (ANOVA) Untuk Densitas Spesimen Uji

\begin{tabular}{|c|c|c|c|c|c|c|}
\hline Response & 3 & \multicolumn{3}{|c|}{ DENSITAS } & & \\
\hline \multicolumn{7}{|c|}{ ANOVA for selected factorial model } \\
\hline \multicolumn{7}{|c|}{ Analysis of variance table } \\
\hline Source & $\begin{array}{l}\text { Sum of } \\
\text { Squares }\end{array}$ & df & $\begin{array}{l}\text { Mean } \\
\text { Square }\end{array}$ & $\begin{array}{c}F \\
\text { Value }\end{array}$ & $\begin{array}{c}F^{*} \\
(\alpha=0.05)\end{array}$ & \\
\hline Model & 2.30 & 3 & 0.77 & 347.73 & 4.07 & $\underline{\text { significant }}$ \\
\hline A-Kompaksi & 1.56 & 1 & 1.56 & 706.10 & 5.32 & \\
\hline B-Holding time & 0.60 & 1 & 0.60 & 271.02 & 5.32 & \\
\hline$A B$ & 0.15 & 1 & 0.15 & 66.08 & 5.32 & \\
\hline Pure Error & 0.018 & 8 & $2.2056 \mathrm{E}-03$ & & & \\
\hline Cor Total & 2.32 & 11 & & & & \\
\hline
\end{tabular}

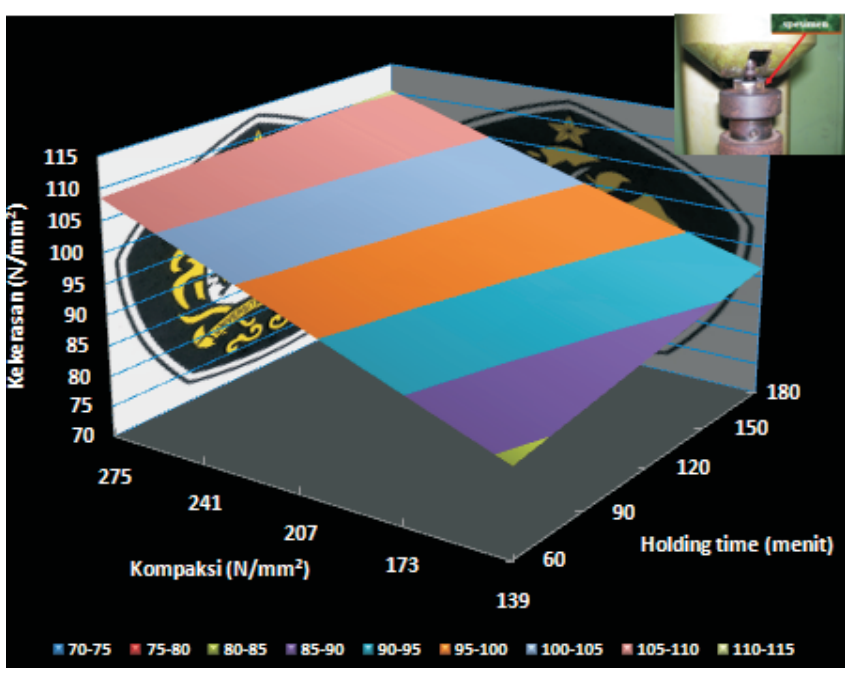

Gambar 6 : Grafik 3D Pengaruh Kompaksi Dan Holding Time Terhadap Nilai Kekerasan

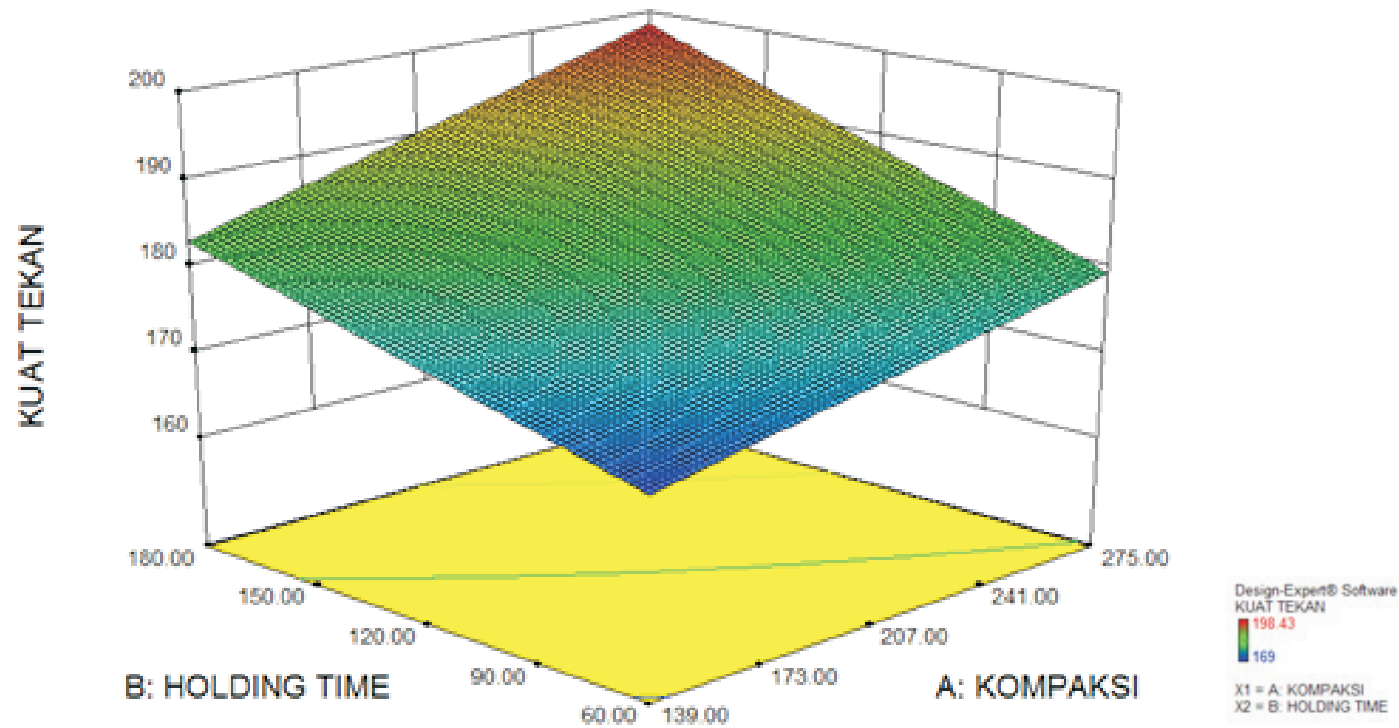

Gambar 7. Grafik 3D Pengaruh Kompaksi Dan Holding Time Terhadap Nilai Kuat Tekan 


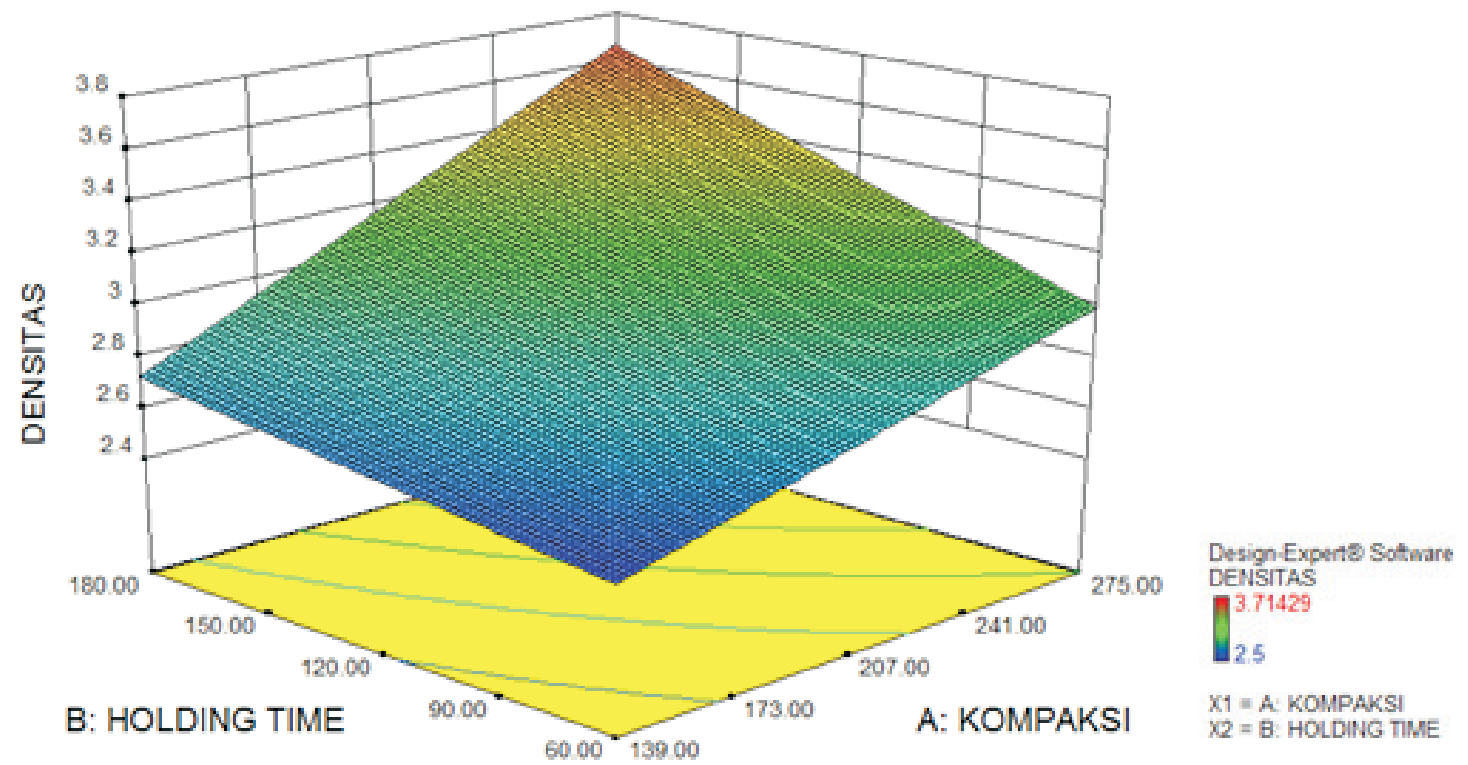

Gambar 8 : Grafik 3D Pengaruh Kompaksi Dan Holding Time Terhadap Nilai Densitas

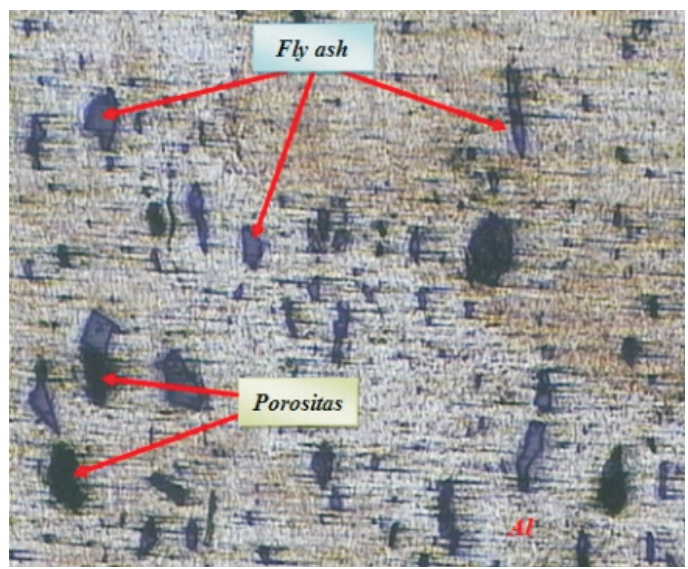

Gambar 9: Mikro Struktur Paduan Al/5\% Fly Ash Dengan Pembesaran 50X Pada Kompaksi 139 N/Mm² Dan Holding Time 60 Menit

\subsection{Optimasi Desain}

Setelah dilakukan uji dengan berbagai respon, selanjutnya dilakukan optimasi desain untuk menentukan kondisi optimum dari kekerasan, kuat tekan dan densitas paduan aluminium $/ 5 \%$ fly ash yang dibuat dengan metode serbuk berdasarkan level minimum dan maksimum dari masing-masing faktor yang ditentukan yaitu kompaksi dan holding time. Nilai maksimum dan minimum yang diperoleh dari respon-respon berdasarkan hasil percobaan aktual dapat dilihat pada gambar 10 , sedangkan nilai level dari kompaksi dan holding time pada gambar 11.

Solusi optimum untuk mendapatkan nilai maksimal dari respon dengan faktor kompaksi dan holding time berdasarkan desain eksperimen 2 level factorial dengan ANOVA yang dibuat dengan bantuan perangkat lunak design-expert dapat dilihat pada tabel 7. Dari hasil eksperimen aktual diperoleh nilai maksimum kekerasan, kuat tekan dan densitas paduan aluminium/fly ash adalah $101.691 \mathrm{~kg} / \mathrm{mm}^{2}, 198,43 \mathrm{~N} / \mathrm{mm}^{2}$ dan $3.714 \mathrm{gr} / \mathrm{cm}^{3}$ yang diperoleh pada tekanan kompaksi $275 \mathrm{~N} / \mathrm{mm}^{2}$ dan holding time 180 menit. Jika dibandingkan dengan nilai yang didapat dari optimasi desain eksperimen hampir mendekati, sehingga desain eksperimen yang dibuat dapat digunakan untuk menentukan nilai faktor kompaksi dan holding time terhadap nilai respon (kekerasan, kuat tekan dan densitas) yang diharapkan. 


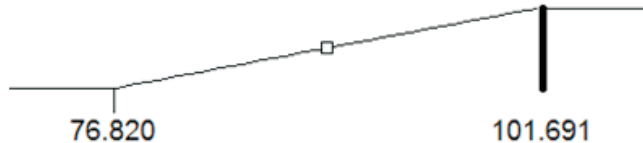

KEKERASAN

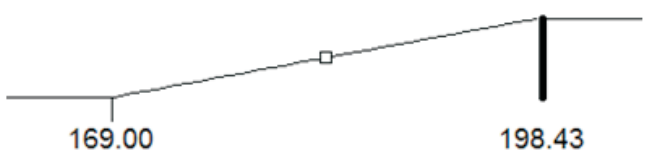

KUAT TEKAN

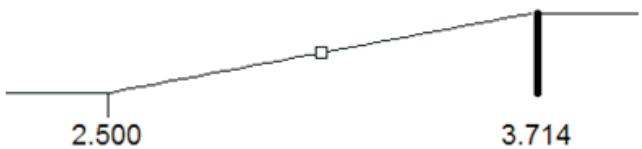

DENSITAS

Gambar 10 : Data Minimum Dan Maksimum Dari Masing-Masing Respon

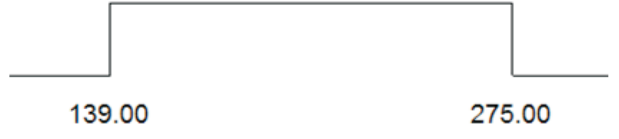

A:KOMPAKSI

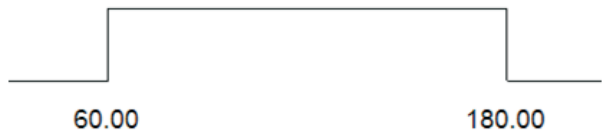

B:HOLDING TIME

Gambar 11 : Level Minimum Dan Maksimum Dari Faktor

Tabel 7. Optimasi Desain Terhadap Nilai Maksimum Dari Respon

\section{No Kompaksi Holding Time Kekerasan Kuat Tekan Densitas}

\begin{tabular}{lllllll}
\hline 1 & $\underline{\mathbf{2 7 5 . 0 0}}$ & $\underline{\mathbf{1 8 0 . 0 0}}$ & $\underline{\mathbf{1 0 1 . 6 7 4}}$ & $\underline{\mathbf{1 9 8 . 4 1}}$ & $\underline{\mathbf{3 . 6 6 7}}$ & selected \\
\hline 2 & 275.00 & 178.23 & 101.592 & 198.29 & 3.662 & \\
3 & 275.00 & 169.19 & 100.522 & 196.70 & 3.607 & \\
\hline
\end{tabular}

\section{KESIMPULAN}

Berdasarkan hasil eksperimen dan analisa data yang dilakukan terhadap paduan aluminium $/ 5 \%$ fly ash yang dibuat dengan metode metallurgi serbuk dengan faktor tekanan pemadatan (kompaksi) dan waktu penahanan suhu sinter (holding time) dapat diambil kesimpulan sebagai berikut :

1. Berdasarkan analisa data hasil percobaan terhadap spesimen uji dengan metode 2 level factorial design dan ANOVA menggunakan perangkat lunak design expert diperoleh $\mathrm{F}_{\text {Hitung }}>$ $\mathrm{F}_{\text {Tabel, }}$, sehingga dapat disimpulkan bahwa faktor kompaksi dan holding time berpengaruh terhadap nilai kekerasan, kuat tekan dan densitas dari spesimen uji dengan tingkat keyakinan $95 \%(\alpha=0.05)$.
2. Faktor yang paling berpengaruh terhadap kekerasan dan kuat tekan paduan aluminium dengan fly ash pada proses pembuatan paduan menggunakan metode metallurgi serbuk serta suhu sinter $550^{\circ} \mathrm{C}$ dan fraksi penguat fly ash $5 \%$ adalah holding time sedangkan untuk densitas paling dominan adalah kompaksi, kedua faktor mempunyai pengaruh positif terhadap respon, sehingga dengan naiknya kompaksi dan holding time dapat meningkatkan kekerasan, kuat tekan dan densitas paduan.

3. Nilai respon optimum berdasarkan eksperimen aktual dan ANOVA terdapat pada kompaksi $275 \mathrm{~N} / \mathrm{mm}^{2}$ dan holding time 180 menit, sedangkan dari percobaan aktual yang dilakukan diperoleh nilai tertinggi dari kekerasan 
brinell=101.691 HB2,5/62,5/30, kuat t e k a n $=198.43 \mathrm{~N} / \mathrm{m} \mathrm{m}^{2}$ d a n densitas $=3.714 \mathrm{gr} / \mathrm{cm}^{3}$.

4. Desain eksperimen dengan bantuan perangkat lunak design expert dapat membantu mempercepat analisa data hasil eksperimen serta mengontrol eksperimen aktual yang dilakukan dan menentukan parameter optimal untuk mendapatkan hasil respon yang diinginkan.

\section{DAFTAR PUSTAKA}

1. Amstead, B.H. et.al., (Sriati Djaprie), “Teknologi Mekanik", Erlangga, Jakarta, Guneet Senthi, "Microwave Sintering of Cu-12Sn", Indian Institute of Technology, India

.2. Arik, H. dan Chengiz, B., 2001, "Investigation of Influences of Pressing and Sintering Temperature on the Mechanical Properties of $\mathrm{Al}-\mathrm{AlC}_{4} \mathrm{O}_{3}$ Composite Materials", Turkish J. Eng. Env. Sei, 53-58.

3. ASTM Standards, 2003, "Metals Test Methods and Analytical Procedures", Volume 03.01.

4. Bienas, J., Walezak, M., Surowska, B., dan Sobezak, J., 2003, "Microstructure and Corrosion Behavior of Aluminium Fly Ash Composites", Journal of Optoelectronics and Advanced Materials, Vo1.5, No.2, June 2003, pp.493-502.

5. Ejiofor, J.U., dan Reddy R.G., 1997, "Development in the Processing and Properties of Particulate AL-Si Composites", Journals JOM is Published of the minerals. Metals \& Materials Society, 49 (11), pp 31-37.

6. E. Paul DeGarmo, 2003, "Materials And Processes In Manufacturing", Ninth Edition, John Wiley \& Sons, Inc.

7. Graham Withers, 2008, "Utilizing Fly Ash Particles To Reduce Low Cost Metal Matrix Composites", Ultalite, Melbourne, Australia.

8. Groover, M. P., 2007, "Fundamental of Modern Manufacturing Material, Process and System", Third Edition, John Wiley \& Sons, Inc.

9. Johan Trygg, Svante Wold, 2002, "Introduction To Statistical Experiment Design”, University Of Queensland,
10. R. Ganesh Narayanan, "Powder Metallurgy - Basic \& Aplication", http://www.iitg.ernet.in/engfac/ganu/pub lic html/Part2-09.pdf diunduh tanggal 21-02-2011

11. Shuvendu Tripathy, 2009, "Study on Aluminium Fly Ash Composite Produced by Impeller Mixing", Thesis S2, National Institute Of Technology Rourkela.

12. William E. Murphy, 2007, "Using DesignExpert For Enchancing Engineering Experimentation Labs", ASEE Southheast Section Conference, University Of Kentucky.

\section{RIWAYAT PENULIS}

Djoko W. Karmiadji, lahir di Banyuwangi tanggal 10 Februari 1957. Menamatkan pendidikan S1 di Jurusan Teknik Mesin, Universitas Gadjah Mada pada tahun 1983. Sebagai peneliti tamu di DFVLR, Cologne, Jerman dari April 1986 - April 1987 dibidang pengujian fatigue material pesawat. Menyelesaikan pendidikan S2 dan S3 pada tahun 1992 dan 1997 di Mechanical Engineering Department, the University of Alabama, USA. Bekerja sejak tahun 1984 di UPT Laboratorium Uji Konstruksi / B2TKS BPP Teknologi di bidang Pengujian Komponen dan Konstruksi sebagai Ahli Peneliti Utama. Menjadi guru besar di Fakultas Teknik Universitas Pancasila. Penulis juga menjadi anggota organisasi profesional SAE International dan IATO/SAE Indonesia.

Dicky Seprianto, lahir di Palembang tanggal 16 September 1977. Menamatkan Pendidikan D3 di Jurusan Teknik Mesin, Politeknik Universitas Sriwijaya pada tahun 1998. Menyelesaikan pendidikan S1 di Jurusan Teknik Mesin Universitas Sriwijaya tahun 2000 dan S2 di Program Magister Teknik Mesin, Universitas Pancasila pada tahun 2010. Bekerja sejak tahun 2001 sampai sekarang sebagai Staf Pengajar, serta tahun 2009 sampai sekarang sebagai tim perencanaan Politeknik Negeri Sriwijaya dan sekretaris redaksi jurnal Austenit Jurusan Teknik Mesin Politeknik Negeri Sriwijaya di Palembang. 